\section{Antifungal agents for common paediatric infections}

$\mathrm{T}$ he most common fungal infections in infants and children are mucocutaneous candidiasis, pityriasis versicolor, tinea corporis, tinea pedis and tinea capitis (1). The objective of the present update is to inform clinicians on options for treatment of these symptomatic fungal infections, due to a variety of over-the-counter (Table 1) and prescription (Table 2) drugs available. It replaces the previous position statement published in 2000 (2).

\section{MUCOCUTANEOUS CANDIDIASIS}

Candida albicans colonization can occur as early as the first week of life. Symptomatic infections such as thrush and Candida diaper dermatitis (CDD) may develop at any age thereafter, particularly following broad-spectrum antibiotic treatment. Systemic candidiasis is rare, but is a particular risk for premature infants $(3,4)$.

Although mucocutaneous candidiasis is common, only a few high-quality randomized control studies of drug therapy have been published. In fact, one recent review (5) of oral candidiasis in patients with cancer found only eight studies that met the inclusion criteria. Control trials for diaper dermatitis are also rare, making it difficult to derive recommendations for optimal therapy.

\section{Oropharyngeal candidiasis (thrush)}

Oropharyngeal candidiasis (thrush) may start as early as seven days after birth, with an incidence in infants of $5 \%$ to $10 \%$ depending on the population studied (6-7). Response to antifungal agents is usually good in neonates with no major underlying condition, but a prolonged course may be required and recurrences are common. Use of an infant soother increases the incidence of thrush and may make treatment less effective, unless the soother is carefully washed after use (8).

Topical gentian violet, the oldest therapeutic agent, is moderately effective against thrush but prolonged use can cause irritation and even ulceration (9). Gentian violet stains tissue and clothing and, thus, is not well accepted by parents; it also interferes with clinical assessment.

Nystatin suspension has been used since the 1950s (10). It is well tolerated and remains the most frequently prescribed agent for thrush. The usual dosage of 200,000 units four times daily is highly effective, curing $50 \%$ of newborns after one week and $80 \%$ of newborns after two weeks of treatment (11). It should be administered after feeds.

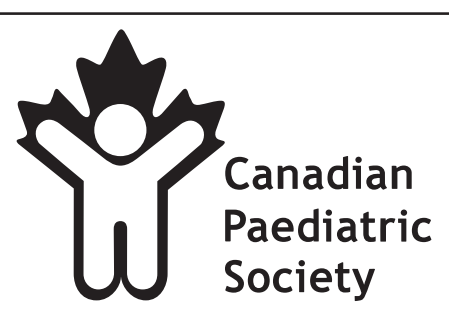

Français en page 879

First-generation imidazoles, such as miconazole and clotrimazole, are more effective than nystatin (12). However, miconazole gel and oral preparation of clotrimazole are not licensed in Canada. Chronic oral candidiasis can respond to clotrimazole troches (13). There is also anecdotal experience that clotrimazole suppositories in a pacifier or clotrimazole vaginal cream applied to the oral mucosa after feedings are effective against thrush $(14,15)$. Because these therapeutic approaches have not been evaluated in controlled trials, they are not recommended as first-line therapies.

Second-generation imidazoles, such as fluconazole and itraconazole or other new oral antifungals, may be considered if conventional topical treatments fail, particularly among immunocompromised patients. Although these drugs are effective, they are not recommended as first-line management of thrush in normal children because of limited paediatric data, potentially significant adverse effects and high costs.

\title{
CDD
}

CDD is common during the second to fourth months of life in healthy infants $(7,8)$. Candida albicans is present in the feces of $90 \%$ of such infants $(13,16)$. Treatment should include decreasing maceration of the skin by eliminating impervious diaper covers, changing diapers frequently and leaving diapers off for long periods of time. Topical antifungal therapy is also necessary. In one randomized, double-blind, controlled trial (17) comparing miconazole ointment with zinc oxide petroleum base, miconazole was safe and more effective, particularly in moderate to severe cases. Ointments, creams and powders of nystatin, miconazole and clotrimazole are available (Table 1). It is still not clear whether concomitant oral and topical antifungals should be recommended. In two studies $(18,19)$, no difference in the initial clinical responses was found. In another study (18), relapses were decreased (although not significantly) when an oral supplement of nonabsorbable nystatin was added to the topical ointment of nystatin (16\% versus 33\%).

There are no well-designed trials to assess the efficacy of adding a topical anti-inflammatory agent in treatment of CDD. Potent anti-inflamatory preparations, such as those with high concentrations of steroids, may impair the response to antifungal agents and should be avoided. The place for low concentrations of steroids (eg, 1\% hydrocortisone) is unclear. Although some experts never use steroids with antifungal agents, others advocate them in CDD. 


\section{TABLE 1}

\section{Selected topical antifungal agents for children}

\begin{tabular}{|c|c|}
\hline Antifungal agents & Cost \\
\hline $\begin{array}{l}\text { Nystatin cream, ointment or powder: Over-the-counter (OTC) } \\
\text { preparations include Candistatin*, Mycostatin }{ }^{\dagger} \text { and ratio-Nystatin }\end{array}$ & $\$$ \\
\hline $\begin{array}{l}\text { Oral suspension }(100,000 \mathrm{U} / \mathrm{mL}): 100,000 \mathrm{U} \text { to } 200,000 \mathrm{U} \\
\text { three to four times daily for thrush }\end{array}$ & $\$ \$$ \\
\hline $\begin{array}{l}\text { Clotrimazole: OTC - Canesten } \$ \text {, Clotrimaderm }{ }^{\Uparrow} \\
1 \% \text { two times daily for seven days (maximum } 14 \text { days) }\end{array}$ & $\$ \$$ \\
\hline $\begin{array}{l}\text { Ketoconazole cream: Nizoral }{ }^{* *} \text { cream } \\
2 \% \text { once daily }\end{array}$ & $\$ \$$ \\
\hline $\begin{array}{l}\text { Ketoconazole shampoo: OTC - Nizoral†† shampoo } \\
2 \% \text { once daily }\end{array}$ & $\$ \$$ \\
\hline $\begin{array}{l}\text { Miconazole cream or ointment: OTC }- \text { Micatin }{ }^{\dagger \dagger}, \text { Micozoleף, } \\
\text { Monistat** } \\
2 \% \text { one to two times daily }\end{array}$ & $\$ \$$ \\
\hline $\begin{array}{l}\text { Terbinafine cream: Lamisil } \$ \ddagger \\
1 \% \text { one to two times daily }\end{array}$ & $\$ \$ \$$ \\
\hline $\begin{array}{l}\text { Gentian violet liquid: OTC } \\
1 \% \text { to } 2 \% \text { twice daily }\end{array}$ & $\$$ \\
\hline $\begin{array}{l}\text { Selenium sulfide: OTC - Versel§§ lotion } 2.5 \% \text {, } \\
\text { Selsun }{ }^{\Uparrow \Uparrow} \text { shampoo } 1 \% \\
\text { Daily }\end{array}$ & $\$ \$$ \\
\hline
\end{tabular}

The relative cost per $30 \mathrm{~g}$ treatment is indicated. Approximate relative cost for $30 \mathrm{~g}$ treatment includes the prescription fee (if applicable) and is based on data from 2007. Major variation in the price of products and prescription fees occur among provinces and stores. Relative price has been indicated as follows: $\$$ less than $\$ 10, \$ \$$ from $\$ 10$ to $\$ 25, \$ \$ \$$ from $\$ 25$ to $\$ 50$. * BristolMyers Squibb Canada; †ConvaTec (Canada); ¥ratio Pharm Inc, Canada; §Bayer AG, Germany; TTaro Pharmaceuticals Inc, Canada; ${ }^{* *}$ McNeil Consumer Healthcare, Canada (presciption for Nizoral cream); ††Johnson \& Johnson Inc, Canada; ${ }^{\ddagger}$ Novartis AG, Switzerland; §§Valeo Pharma Inc, Canada; शा Chattem Inc, Canada

\section{PITYRIASIS VERSICOLOR (TINEA VERSICOLOR)}

Pityriasis versicolor is a mild or chronic condition characterized by scaly hypo- or hyperpigmented lesions on the trunk. Infection often occurs in adolescents when the sebaceous glands are active. Malassezia, an organism restricted to invading the stratum corneum (20), causes the infection (21). Antifungal preparations can be effective, but recurrences are common (22).

Topical ketoconazole, selenium sulfide and clotrimazole are the most common treatments (23). Treatment usually consists of applying shampoo preparations, such as ketoconazole $2 \%$ or selenium sulfide as a $2.5 \%$ lotion or $1 \%$ shampoo, to the affected area for $15 \mathrm{~min}$ to 30 min nightly for one to two weeks, and then once a month for three months to avoid recurrences (24). In one randomized trial (25) using ketoconazole shampoo for three days or one day compared with placebo, the response was $73 \%, 69 \%$ and $5 \%$, respectively.

\section{TINEA CORPORIS}

Tinea corporis (ringworm) is a superficial infection of the skin that is not covered by hair. It can occur at any age. Lesions are circular (thus the name ringworm). Common causes in Canada include Trichophyton rubrum, Trichophyton mentagrophytes and Microsporum species (especially Microsporum canis and Epidermophyton floccosum). These are
TABLE 2

Oral absorbable antifungal agents for common fungal infections in children

\begin{tabular}{lr}
\hline Antifungal agents & Cost \\
\hline Ketoconazole $5 \mathrm{mg} / \mathrm{kg} /$ day to $10 \mathrm{mg} / \mathrm{kg} /$ day & $\$ \$ \$$ \\
$\quad$ (100 $\mathrm{mg}$ to $200 \mathrm{mg}$ daily) & \\
Fluconazole $3 \mathrm{mg} / \mathrm{kg} /$ day to $5 \mathrm{mg} / \mathrm{kg} /$ day once daily & $\$ \$ \$ \$$ \\
Using $100 \mathrm{mg}$ tablets & $\$ \$ \$ \$ \$$ \\
Using $10 \mathrm{mg}$ liquid & \\
Itraconazole $5 \mathrm{mg} / \mathrm{kg} /$ day (maximum dose $400 \mathrm{mg}$ daily) & $\$ \$ \$ \$$ \\
Using $100 \mathrm{mg}$ capsules & $\$ \$ \$ \$ \$$ \\
Using $10 \mathrm{mg} / \mathrm{mL}$ liquid & \\
Terbinafine & $\$ \$ \$$ \\
For a child under $20 \mathrm{~kg}: 62.5 \mathrm{mg} /$ day taken once daily & $\$ \$ \$$ \\
For a child $20 \mathrm{~kg}$ to $40 \mathrm{~kg}: 125 \mathrm{mg} /$ day taken once daily & $\$ \$ \$ \$$ \\
\hline For a child over $40 \mathrm{~kg}: 250 \mathrm{mg} /$ day taken once daily &
\end{tabular}

Azoles (ketoconazole, fluconazole and itraconazole) may interfere with metabolism of other drugs (see drug interaction). Prescription is required for all mentioned agents. Approximate relative cost includes the prescription fee and is based on data from 2007. Major variation in the price of products and prescription fees occur among provinces and stores. Relative price has been indicated as follows: $\$ \$ \$$ from $\$ 25$ to $\$ 50, \$ \$ \$ \$$ from $\$ 50$ to $\$ 100, \$ \$ \$ \$ \$$ more than $\$ 100$. Cost estimate is based on treating a $20 \mathrm{~kg}$ child for two weeks

transmitted by direct contact with infected humans, animals (usually dogs and cats) or rarely by fomites (26). There is little difference in efficacy among clotrimazole, ketoconazole, miconazole or terbinafine. A good response usually occurs when any of these agents are applied once or twice daily for 14 to 21 days. Topical agents mixed with corticosteroids should be avoided (24).

\section{TINEA PEDIS}

Tinea pedis (athlete's foot) is a common superficial fungal infection of the foot. Causes include $T$ rubrum, $T$ mentagrophytes and $\mathrm{E}$ floccosum. Although tinea pedis often spreads among household members, it is uncommon in young children $(26,27)$.

Many topical antifungals are effective against tinea pedis. Drying agents, such as Burow's solution, may be a useful adjunct for macerated or vesicular lesions. Recurrence of the infection can be prevented with good foot hygiene. Oral antifungals are indicated for infections involving the toenails. Clinical studies in children are limited, but suggest that fluconazole, itraconazole and terbinafine are effective $(28,29)$.

\section{TINEA CAPITIS AND SEBORRHEIC DERMATITIS}

Tinea capitis (fungal infection of the scalp) is the most common paediatric superficial dermatophyte infection. The causative species vary geographically; $M$ canis predominates in Europe, whereas Trichophyton tonsurans predominates in North America. Because tinea capitis does not respond well to topical therapy alone, oral therapy is required (Table 2) (26).

Seborrheic dermatitis and pityriasis capitis (cradle cap) are common, but usually mild, scalp infections caused by Malassezia species (eg, Malassezia furfur). The condition 
often resolves with mild soap application. Shampoos containing selenium sulfide or an azole are useful in severe forms.

\section{ORAL ANTIFUNGAL AGENTS ABSORBED SYSTEMICALLY}

\section{Fluconazole}

Fluconazole is a triazole with activity against Candida species, some dermatophytes and many systemic mycoses. The drug is hydrophilic and, thus, present mainly in bodily fluids rather than in keratin or lipids (30). It is, therefore, not useful for routine treatment of most superficial fungal infections $(31,32)$.

\section{Griseofulvin}

Griseofulvin is no longer available in Canada.

\section{Itraconazole}

Itraconazole is an azole with activity against many dermatophytes, Candida species, $M$ furfur and some moulds. It has a long half-life in the skin and nails, an affinity for both lipids and keratin, and reaches the skin primarily through sebum. The drug may be excreted in sebum for one month after therapy has been discontinued. Itraconazole is available in tablet and liquid formats. Clinical trials and case series using itraconazole to treat tinea capitis have shown it to be effective (approximately 90\% of the time) for infections caused by either Trichophyton and Microsporum species (33-37). Few side effects were seen in most studies using $3 \mathrm{mg} / \mathrm{kg} /$ day to $5 \mathrm{mg} / \mathrm{kg} /$ day for four to six weeks. Although more studies on safety are needed, itraconazole may become a good first-line agent for tinea capitis.

\section{Ketoconazole}

Ketoconazole was the first azole evaluated for efficacy in the treatment of resistant superficial fungal infections such as tinea capitis. Ketoconazole was found to be equivalent to griseofulvin for such cases in these clinical trials $(38-41)$.

\section{Terbinafine}

Terbinafine is a lipophilic and keratinophilic fungicidal agent, active in vitro against dermatophytes and some moulds. It diffuses to keratinocytes from the blood stream to reach the stratum corneum and hair follicles (42). Because it is not metabolized through cytochrome P-450, many of the drug interactions seen with the azoles do not occur. Terbinafine is well tolerated, with gastrointestinal and skin reactions in only $2 \%$ to $7 \%$ of patients. Loss of the sense of taste has been reported, but resolves after therapy has ended.

Oral terbinafine is effective in the treatment of relatively resistant superficial dermatophyte infections including tinea unguium (onychomycosis), tinea pedis and tinea corporis or tinea cruris, achieving mycological cure in over $80 \%$ of adult patients (43). It is effective for children with tinea capitis at a dose of $62.5 \mathrm{mg} /$ day to $250 \mathrm{mg} /$ day for four weeks (44-48). Topical terbinafine $1 \%$ formulations have been effective when applied once or twice daily for two weeks. Gupta et al (49) concluded that terbinafine may be the drug of choice for superficial fungal infections in children. Terbinafine is available in Canada as a topical 1\% cream and orally as a $250 \mathrm{mg}$ tablet. No liquid formulation is available.

\section{Drug interactions}

The extent to which an antifungal agent interacts with the hepatic P-450 enzyme system has implications on its potential to cause significant drug interactions (50). Azoles are metabolized by cytochrome P-450 3A (CYP 3A) and may inhibit the elimination of other drugs metabolized by this enzyme such as antiarrhythmics, cortisol, cyclosporin, estradiol and tacrolimus. Terbinafine is not an azole; it does not affect CYP 3A and it has few drug interactions.

For further details on the use of antifungal agents for common paediatric infections, the reader is referred to recent review articles $(1,49,51)$.

\section{REFERENCES}

1. Gupta AK, Cooper EA, Ryder JE, Nicol KA, Chow M, Chaudhry MM. Optimal management of fungal infections of the skin, hair, and nails. Am J Clin Dermatol 2004;5:225-37.

2. Canadian Paediatric Society, Infectious Diseases and Immunization Committee [Principal Author: S King]. Antifungal agents for common paediatric infections. Paediatr Child Health 2000;5:477-82.

3. Linder N, Levit $O$, Klinger $G$, et al. Risk factors associated with candidaemia in the neonatal intensive care unit: A case-control study. J Hosp Infect 2004;57:321-4.

4. Yamamura DL, Rotstein C, Nicolle LE, Ioannou S. Candidemia at selected Canadian sites: Results from the Fungal Disease Registry, 1992-1994. CMAJ 1999;160: 493-9.

5. Clarkson JE, Worthington HV, Eden OB. Interventions for treating oral candidiasis for patients with cancer receiving treatment. Cochrane Database Syst Rev 2004;(1):CD001972.

6. Butler KM, Baker CJ. Candida: An increasingly important pathogen in the nursery. Pediatr Clin North Am 1988;35:543-63.

7. Baley JE, Kliegman RM, Boxerbaum B, Fanaroff AA. Fungal colonization in the very low birth weight infant. Pediatrics 1986;78:225-32.

8. Sio JO, Minwalla FK, George RH, Booth IW. Oral candida: Is dummy carriage the culprit? Arch Dis Child 1987;62:406-8.

9. Faber HK, Dickey LB. The treatment of thrush with gentian violet. JAMA 1925;85:900-1.

10. Huang NN, Sarria A, High RH. Therapeutic evaluation of nystatin and amphotericin in oral moniliasis in infants and children. Antibiot Annu 1957-1958;5:59-64.

11. Boon JM, Lafeber HN, Mannetje AH, et al. Comparison of ketoconazole suspension and nystatin in the treatment of newborns and infants with oral candidiasis. Mycoses 1989;32:312-5.

12. Hoppe JE. Treatment of oropharyngeal candidiasis in immunocompetent infants: A randomized multicenter study of miconazole gel versus nystatin suspension. The Antifungals Study Group. Pediatr Infect Dis J 1997;16:288-93.

13. Kirkpatrick CH, Alling DW. Treatment of chronic oral candidiasis with clotrimazole troches. A controlled clinical trial. N Engl J Med 1978;299:1201-3.

14. Mansour A, Gelfand EW. A new approach to the use of antifungal agents in children with persistent oral candidiasis. J Pediatr 1981;98:161-2.

15. Grossman ER. Treatment of thrush. Pediatr Infect Dis J 1988;7:303.

16. Rebora A, Leyden JJ. Napkin (diaper) dermatitis and gastrointestinal carriage of Candida albicans. Br J Dermatol 1981;105:551-5.

17. Concannon P, Gisoldi E, Phillips S, Grossman R. Diaper dermatitis: A therapeutic dilemma. Results of a double-blind placebo controlled trial of miconazole nitrate $0.25 \%$. Pediatr Dermatol 2001;18:149-55.

18. Dixon PN, Warin RP, English MP. Alimentary Candida albicans and napkin rashes. Br J Dermatol 1972;86:458-62. 
19. Munz D, Powell KR, Pai CH. Treatment of candidal diaper dermatitis: A double-blind placebo-controlled comparison of topical nystatin with topical plus oral nystatin. J Pediatr 1982;101:1022-5.

20. Schwartz RA. Superficial fungal infections. Lancet 2004;364:1173-82.

21. Gupta AK, Batra R, Bluhm R, Faergemann J. Pityriasis versicolor. Dermatol Clin 2003;3:413-29.

22. Ginsberg CM. Malassezia species. In: Long SS, Pickering LK, Prober CG, eds. Principles and Practice of Pediatric Infectious Diseases. New York: Churchill Livingston, 1997:1337-8.

23. Mellen LA, Vallee J, Feldman SR, Fleischer AB Jr. Treatment of pityriasis versicolor in the United States. J Dermatolog Treat 2004; 15:189-92.

24. Gupta AK, Einarson TR, Summerbell RC, Shear NH. An overview of topical antifungal therapy in dermatomycoses. A North American perspective. Drugs 1998;55:645-74.

25. Lange DS, Richards HM, Guarnieri J, et al. Ketoconazole $2 \%$ shampoo in the treatment of tinea versicolor: A multicenter, randomized, double-blind, placebo controlled trial. J Am Acad Dermatol 1998;39:944-50.

26. Ginsberg CM. Dermatophytes and other superficial fungi. In: Long SS, Pickering LK, Prober CG, eds. Principles and Practice of Pediatric Infectious Diseases. New York: Churchill Livingston, 1997:1359-62.

27. Gupta AK, Sibbald RG, Lynde CW, et al. Onychomycosis in children: Prevalence and treatment strategies. J Am Acad Dermatol 1997;36:395-402.

28. Bräutigam M. Terbinafine versus itraconazole: A controlled clinical comparison in onychomycosis of toenails. J Am Acad Dermatol 1998;38:S53-6.

29. De Backer M, De Vroey C, Lesaffre E, Scheys I, De Keyser P. Twelve weeks of continuous oral therapy for toenail onychomycosis caused by dermatophytes: A double-blind comparative trial of terbinafine $250 \mathrm{mg} /$ day versus itraconazole $200 \mathrm{mg} /$ day. J Am Acad Dermatol 1998;38:S57-63.

30. Grant SM, Clissold SP. Fluconazole: A review of its pharmacodynamic and pharmacokinetic properties, and therapeutic potential in superficial and systemic mycoses. Drugs 1990;39:877-916. (Erratum in 1990;40:862).

31. Gatti S, Marinaro C, Bianchi L, Nini G. Treatment of kerion with fluconazole. Lancet 1991;338:1156.

32. Solomon BA, Collins R, Sharma R, et al. Fluconazole for the treatment of tinea capitis in children. J Am Acad Dermatol 1997;37:274-5.

33. López-Gómez S, Del Palacio A, Van Cutsem J, Soledad Cuétara M, Iglesias L, Rodriguez-Noriega A. Itraconazole versus griseofulvin in the treatment of tinea capitis: A double-blind randomized study in children. Int J Dermatol 1994;33:743-7.

34. Legendre R, Esola-Macre J. Itraconazole in the treatment of tinea capitis. J Am Acad Dermatol 1990;23:559-60.

35. Lukacs A, Korting HC, Lindner A. Successful treatment of griseofulvin-resistant tinea capitis in infants. Mycoses 1994;37:451-3.
36. Elewski BE. Tinea capitis: Itraconazole in Trichophyton tonsurans infection. J Am Acad Dermatol 1994;31:65-7.

37. Greer DL. Treatment of tinea capitis with itraconazole. J Am Acad Dermatol 1996;35:637-8.

38. Tanz RR, Stagl S, Esterly NB. Comparison of ketoconazole and griseofulvin for the treatment of tinea capitis in childhood: A preliminary study. Pediatr Emerg Care 1985;1:16-8.

39. Tanz RR, Hebert AA, Esterly NB. Treating tinea capitis: Should ketoconazole replace griseofulvin? J Pediatr 1988;112:987-91.

40. Gan VN, Petruska M, Ginsburg CM. Epidemiology and treatment of tinea capitis: Ketoconazole vs griseofulvin. Pediatr Infect Dis J 1987;6:46-9.

41. Martinez-Roig A, Torres-Rodriguez JM, Bartlett-Coma A. Double-blind study of ketoconazole and griseofulvin in dermatophytoses. Pediatr Infect Dis J 198;7:37-40.

42. Faergemann J, Zehender H, Denouël J, Millerioux L. Levels of terbinafine in plasma, stratum corneum, dermis-epidermis (without stratum corneum), sebum, hair and nails during and after $250 \mathrm{mg}$ terbinafine orally once per day for four weeks. Acta Derm Venerol 1993;73:305-9.

43. McClellan KJ, Wiseman LR, Markham A. Terbinafine. An update of its use in superficial mycoses. Drugs 1999;58:179-202.

44. Haroon TS, Hussain I, Mahmood A, Nagi AH, Ahmad I, Zahid M An open clinical pilot study of the efficacy and safety of oral terbinafine in dry non-inflammatory tinea capitis. Br J Dermatol 1992;126(Suppl 39):47-50.

45. Nejjam F, Zagula M, Cabiac MD, Guessous N, Humbert H, Lakhdar H. Pilot study of terbinafine in children suffering from tinea capitis: Evaluation of efficacy, safety and pharmacokinetics. Br J Dermatol 1995;132:98-105.

46. Alvi KH, Iqbal N, Khan KA, et al. A randomized double-blind trial of the efficacy and tolerability of terbinafine once daily compared to griseofulvin once daily in treatment of tinea capitis. In: Shuster S, Jafary MH, eds. Royal Society of Medicine Services International Congress Series, no 205. London: Royal Society of Medicine Press Ltd, 1992:35-40.

47. Haroon TS, Hussain I, Aman S, et al. A randomized double-blind comparative study of terbinafine for 1,2 and 4 weeks in tinea capitis. Br J Dermatol 1996;135:86-8.

48. Kullavanijaya P, Reangchainam S, Ungpakorn R. Randomized single-blind study of efficacy and tolerability of terbinafine in the treatment of tinea capitis. J Am Acad Dermatol 1997;37:272-3.

49. Gupta AK, Cooper EA, Lynde CW. The efficacy and safety of terbinafine in children. Dermatol Clin 2003;21:511-20.

50. Albengres E, Le Louet H, Tillement JP. Systemic antifungal agents. Drug interactions of clinical significance. Drug Saf 1998;18:83-97.

51. Howard RM, Frieden HJ. Dermatophyte infections in children. In: Aronoff SC, Hughes WT, Kohl HS, Prince A, eds. Advances in Pediatric Infectious Diseases, Vol 14. St Louis: Mosby-Year Book, 1999:73-108.

\section{INFECTIOUS DISEASES AND IMMUNIZATION COMMITTEE}

Members: Drs Robert Bortolussi, IWK Health Centre, Halifax, Nova Scotia (chair); Dorothy L Moore, The Montreal Children's Hospital, Montreal, Quebec; Joan Louise Robinson, Edmonton, Alberta; Élisabeth Rousseau-Harsany, Sainte-Justine UHC, Montreal, Quebec (board representative); Lindy Michelle Samson, Children's Hospital of Eastern Ontario, Ottawa, Ontario

Consultant: Dr Noni E MacDonald, IWK Health Centre, Halifax, Nova Scotia

Liaisons: Drs Upton Dilworth Allen, The Hospital for Sick Children, Toronto, Ontario (Canadian Pediatric AIDS Research Group); Scott Alan Halperin, IWK Health Centre, Halifax, Nova Scotia (Immunization Program, ACTive); Charles PS Hui, Children's Hospital of Eastern Ontario, Ottawa, Ontario (Health Canada, Committee to Advise on Tropical Medicine and Travel); Larry Pickering, Elk Grove, Illinois, USA (American Academy of Pediatrics, Red Book Editor and ex-officio member of the Committee on Infectious Diseases); Marina Ines Salvadori, Children's Hospital of Western Ontario, Ottawa, Ontario (Health Canada, National Advisory Committee on Immunization)

Principal author: Dr Robert Bortolussi, IWK Health Centre, Halifax, Nova Scotia

The recommendations in this statement do not indicate an exclusive course of treatment or procedure to be followed. Variations, taking into account individual circumstances, may be appropriate. This article also appears in the January/February 2008 issue of The Canadian Journal of Infectious Diseases 83 Medical Microbiology. 